\title{
The Effect of Preoperative Anemia on the Outcome after Coronary Surgery
}

Tuomas Tauriainen, ${ }^{1}$ Joni Koski-Vähälä, ${ }^{1}$ Eeva-Maija Kinnunen, ${ }^{1}$ and Fausto Biancari $^{1}$

${ }^{1}$ Department of Surgery, Oulu University Hospital, Oulu, Finland

Running title: Anemia in coronary surgery

Keywords: Coronary artery bypass; anemia; transfusion.

Grant support: None

Conflicts of interest: None to declare

Manuscript word count: 2490 words

Abstract word count: 231 words

For correspondence:

Prof. Fausto Biancari, Department of Surgery, Oulu University Hospital,

P.O. Box 21, 90029 Oulu, Finland.

Tel.: +358 407333 973;

Fax: + 3588315 2486;

E-mail: faustobiancari@yahoo.it 


\begin{abstract}
Background: Preoperative anemia is associated with increased morbidity and mortality after cardiac surgery. Since anemia is ultimately treated with red blood cell (RBC) transfusions, we investigated the independent impact of anemia and transfusion on the outcome after coronary artery bypass grafting (CABG).
\end{abstract}

Methods: This study included 2761 consecutive patients who underwent isolated CABG. Anemia was defined as hemoglobin $<12.0 \mathrm{~g} / \mathrm{dL}$ in women and $<13.0 \mathrm{~g} / \mathrm{dL}$ in men. The main outcomes were 30-day and late mortality.

Results: Patients with preoperative anemia had an increased prevalence of significant comorbidities and were associated with higher unadjusted risk of early and late adverse events. Propensity score matching resulted in 560 pairs with similar baseline and operative characteristics. In these matched pairs, anemic patients had an increased risk of late all-cause death $(\mathrm{P}=0.047)$ and acute kidney injury $(\mathrm{p}<0.0001)$. However, when adjusted for the severity of perioperative bleeding, preoperative anemia was not associated with an increased mortality risk (HR 1.10, 95\%CI 0.86-1.39). Instead, this regression model showed that the European CABG registry (E-CABG) bleeding classification was an independent predictor of late mortality (compared to grade 0: grade 1, HR 1.93, 95\%CI 1.37-2.73, grade 2, HR 2.19, 95\%CI 1.50-3.18, grade 3, HR 5.59, 95\%CI 3.34-9.39, $\mathrm{P}<0.0001)$.

Conclusions: When adjusted for important baseline characteristics and operative factors as well as for the severity of perioperative bleeding and the amount of transfused blood products, anemia was not associated with an increased risk of adverse events. Increased exposure to blood transfusion among anemic patients may be the determinant of their poorer late survival. 


\section{Introduction}

Anemia and exposure to red blood cell (RBC) transfusion are predictors of adverse events after cardiac and non-cardiac surgery [1-9]. Differentiating the negative effects of these two factors is difficult since preoperative anemia is itself associated with increased need of RBC transfusions $[7,10,11,13-15]$. On the other hand, preoperative anemia is relatively common in patients undergoing cardiac surgery [10] and is a result of multiple causes which in turn are risk factors for poor outcome in these patients [16]. The aim of the present study was to evaluate the independent effect of preoperative anemia on the outcome after coronary artery bypass grafting (CABG).

\section{Materials and methods}

\section{Patients}

The present study includes 2761 consecutive patients who underwent isolated CABG from June 2006 to December 2013 at the Oulu University Hospital, Finland. Complete data on pre-, intra- and postoperative variables were available in these patients. Data on the preoperative use of antithrombotics were retrospectively collected. Data on the types and amount of blood products such as RBCs, platelets and solvent/detergent-treated plasma (Octaplas; Octapharma AG, Lachen, Switzerland) were retrieved from a prospective electronic hospital registry. The amount of transfused blood products was estimated from the day of operation day until discharge or up to a maximum of 30 days after the operation. Data on the amount of chest drainage output at 12 hours after surgery were retrieved from a prospective electronic registry of the intensive care unit. Preoperative anemia was defined a hemoglobin level $<12.0 \mathrm{~g} / \mathrm{dL}$ in 
women and $<13.0 \mathrm{~g} / \mathrm{dL}$ in men [17]. Clinical variables were defined according to the EuroSCORE II definition criteria [18]. The E-CABG classification of bleeding severity [19] was employed to stratify the severity of perioperative bleeding based on the type and amount of blood products transfused and the need of resternotomy for excessive bleeding. The ECABG bleeding grades [19] are: Grade 0, no transfusion of blood products or transfusion of one unit of RBCs; Grade 1, transfusion of platelets, fresh frozen plasma/Octaplas and/or 2-4 units of RBCs; Grade 2, transfusion of 5-10 units of RBCs and/or reoperation for bleeding; Grade 3, transfusion of $>10$ units of RBCs. Data on patients' death were provided up to January 31st, 2016 from the Finnish Population Registry Center, which collects the certificates of death of all inhabitants of Finland. We assume that there are no missing data on any immediate and late death of this study population.

\section{Inclusion criteria}

Patients who underwent any elective, urgent or emergency isolated CABG were included in this analysis.

\section{Perioperative antithrombotic treatment}

Aspirin was discontinued for seven days until 2012 and later on was continued until surgery. Warfarin was discontinued for 2 days before surgery. Enoxaparin was used preoperatively only in patients with acute coronary syndrome. Clopidogrel, prasugrel and ticagrelor were discontinued for at least 5 days when feasible. 
Heparin $(3.0 \mathrm{mg} / \mathrm{kg})$ was administered intraoperatively to maintain an activated coagulation time of longer than 450 seconds and it was neutralized at the end of the procedure by protamine sulphate $(3.0 \mathrm{mg} / \mathrm{kg})$. Aprotinin was not used in any of these patients. Tranexamic acid was administered intraoperatively at discretion of the anesthesiologist. RBCs were transfused on the operation day if hemoglobin was less than $90 \mathrm{~g} / \mathrm{L}$. Later, RBCs were transfused if hemoglobin was less than $80 \mathrm{~g} / \mathrm{L}$. Octaplas as well as platelets were transfused according to the amount of intra- and postoperative bleeding, INR levels and platelet count.

Enoxaparin (40-80 mg once-a-day) was started on the evening of the operation day in those patients without excessive bleeding $(<1000 \mathrm{~mL})$. Aspirin $100 \mathrm{mg}$ was restarted on the first postoperative day. Warfarin was restarted on the first postoperative day in patients on chronic oral anticoagulation unless excessive bleeding occurred. Warfarin was started de novo in case of persistent atrial fibrillation. Clopidogrel and ticagrelor were used postoperatively only in case of allergy to aspirin or recent percutaneous coronary intervention.

\section{Operative techniques and management of chest drainages}

Intermittent antegrade and retrograde cold blood cardioplegia was used during on-pump CABG. Epiaortic ultrasound was performed according to the surgeon's preference. Octopus stabilizer (Medtronic, Minneapolis, MN) as well as intracoronary shunts were routinely used in patients who underwent off-pump surgery. All blood lost during the operation was collected into a cell saver reservoir and washed. Salvaged red blood cells were transfused during or at the completion of the operation. Mediastinal/pleural blood was collected after surgery in a sterile collection chamber connected to $15 \mathrm{~cm} \mathrm{H}_{2} \mathrm{O}$ wall suction via an underwater seal and then 
discarded.

\section{Outcomes}

The primary outcomes of this study were 30-day and late mortality. Secondary outcomes were the length of intensive care unit stay, stroke, atrial fibrillation, ventricular fibrillation or asystole, permanent pace-maker implantation, postoperative use of antibiotics, deep sternal wound infection, mediastinitis, low cardiac output syndrome, repeat revascularization, surgery for gastrointestinal complications, acute kidney injury according to the Kidney Disease: Improving Global Outcomes (KDIGO) criteria based on peak creatinine level during the in-hospital stay [20], nadir hemoglobin level during the postoperative period and chest drain output 12 hours after surgery. Low cardiac output syndrome was defined as postoperative cardiac index $<2.0 \mathrm{~L} / \mathrm{min} / \mathrm{m}^{2}$ as measured at least twice. The other outcomes were defined according to the E-CABG definition criteria as previously reported [19].

\section{Statistical analysis}

Statistical analysis was performed using SPSS statistical software (version 23.0, IBM Corporation, New York, USA). No attempt to replace missing values was made. Continuous variables are reported as the mean and standard deviation. Nominal variables are reported as counts and percentages. Fisher's exact test, Chi-square test and Mann-Whitney tests were used for univariate analysis. Risk estimates are reported as beta coefficients, odds ratio (OR) and hazard rate (HR) with 95\% confidence interval (95\%CI). Observational studies do not provide randomization and therefore propensity score matching method was employed to select two groups of patients with and without preoperative anemia having similar baseline 
and operative characteristics. The propensity score was estimated using a non-parsimonious logistic regression model with the preoperative anemia/non-anemia as the dependent variable. The following variables have been included as covariates: age, gender, body mass index, platelets count, eGFR, dialysis, pulmonary disease, diabetes, stroke, extracardiac arteriopathy, neurological dysfunction, atrial fibrillation, previous percutaneous coronary intervention, previous cardiac surgery, left ventricular ejection fraction $\leq 50 \%$, recent myocardial infarction, critical preoperative status, preoperative intra-aortic balloon pump, recent ventricular arrhythmia, cardiac massage, urgency of the operation, off-pump surgery, epiaortic ultrasound, diseased ascending aorta, bilateral mammary artery grafts and radial artery graft. One-to-one propensity score matching was performed using a caliper width of 0.02 of the standard deviation of the logit of the propensity score. Analysis of the standardized differences after matching was used to assess the balance between the characteristics of propensity-matched pairs. The outcomes of matched groups were evaluated by the t-test for paired sample for continuous variables and the McNemar test for dichotomous variables. Difference in overall survival at 9 years was evaluated by the Kaplan-Meier method. Logistic regression, linear regression, ordinal regression and Cox proportional hazards analyses of propensity matched pairs were adjusted for the E-CABG bleeding grades in order to evaluate the impact of blood transfusion and resternotomy for excessive bleeding on the outcomes. In another regression model, preoperative anemia was adjusted for the number of transfused units of RBCs. All tests were two-sided with the alpha level set at 0.05 for statistical significance.

\section{Results}

Baseline and operative data 
In this series, 662 patients $(24.0 \%, 22.8 \%$ of men and $28.6 \%$ of women) had preoperative anemia. Baseline and operative characteristics of these patients are summarized in Tables 1 and 2 . The prevalence of comorbidities was significantly higher among anemic patients. In particular, anemic patients were significantly older, had a higher prevalence of recent myocardial infarction and were operated mostly on urgent/emergency basis. Operative factors were similar between the study groups.

Outcomes in the overall series

Outcomes in overall series are summarized in Tables 3 and 4. In-hospital, 30-day and longterm mortalities were significantly increased in patients exposed to anemia $(\mathrm{P}<0.0001$ in all). Unadjusted 8-year survival in non-anemic and anemic patients were $80.2 \%$ and $62.4 \%$ respectively.

Preoperative anemia was associated with a significantly increased risk of exposure to blood products (Tab. 3) and lower nadir haemoglobin values $(\mathrm{P}<0.0001)$, whereas blood loss at 12 hours was lower $(484 \pm 416$ vs. $509 \pm 388 \mathrm{ml}, \mathrm{P}=0.029)$ when compared to non-anemic patients.

In univariate analysis, preoperative anemia was associated with significantly longer stay in the intensive care unit, atrial fibrillation, ventricular fibrillation or asystole, postoperative use of antibiotics and acute kidney injury $(\mathrm{P}<0.0001$ in all). The rates of postoperative stroke $(\mathrm{P}=0.001)$, low cardiac output syndrome $(\mathrm{P}=0.003)$ and surgery for gastrointestinal complications $(\mathrm{P}=0.001)$ were also significantly higher among anemic patients. 


\section{Propensity score matched analysis}

Logistic regression (Hosmer-Lemeshow's test: $\mathrm{P}=0.248$ ) provided a propensity score with an area under the receiver-operating characteristics curve of 0.773 (95\%CI 0.753-0.793). Propensity-score matching (caliper width: 0.02) resulted in 560 patient pairs with similar baseline and operative covariates as confirmed by absolute standardized differences $<10 \%$ in all baseline and operative covariates (Fig. 1).

In these propensity matched pairs, in-hospital $(3.0 \%$ vs. $3.2 \%, \mathrm{P}=1.00)$ and 30 -day mortality rates $(3.9 \%$ vs. $3.9 \%, \mathrm{P}=1.00)$ were similar in non-anemics and anemics. However, KaplanMeier analysis showed a better survival among non-anemics at mid-term, but the difference somewhat decreased at long-term follow-up (at 8 years, 68.2\% vs. 66.3, $\mathrm{P}=0.047$, Tab. 4).

Exposure to RBC transfusion was significantly higher among anemic patients (Tab. 3). Similarly, nadir haemoglobin level was significantly lower among patients with preoperative anemia (mean, $7.6 \pm 0.9$ vs. $8.3 \pm 1.1 \mathrm{~g} / \mathrm{dL}, \mathrm{P}<0.0001$ ), but the amount of blood loss at 12 hours (mean, $477 \pm 414$ vs. $494 \pm 376 \mathrm{~mL}, \mathrm{P}=0.408)$ and rates of reoperation for bleeding $(5.2 \% \mathrm{vs}$. $7.1 \%, \mathrm{P}=0.222$ ) were similar between the study groups.

In these propensity score matched pairs, preoperative anemia was associated with a significantly higher rate of acute kidney injury not requiring dialysis $(26.3 \%$ vs. $15.9 \%$, $\mathrm{P}<0.0001$ ), without any increased risk of other early adverse events,

In view of the increased need of $\mathrm{RBC}$ transfusion among patients with preoperative anemia (Tab. 3), analyses in these propensity score matched pairs were further adjusted for the severity of perioperative bleeding/amount of transfusion as stratified by the E-CABG bleeding classification. These adjusted analyses showed that preoperative anemia was 
associated only with an increased risk of acute kidney injury not requiring dialysis (OR 1.50, 95\%CI 1.10-2.03), whereas other early outcomes were similar between anemics and nonanemics (Tab. 3).

Cox proportional hazards model in propensity matched pairs including preoperative anemia and the severity of preoperative bleeding stratified by the E-CABG bleeding classification showed that anemia (HR 1.10, 95\% CI 0.86-1.39, Fig. 2) was not an independent predictor of late death. Instead, this regression model showed that the E-CABG bleeding classification was an independent predictor of mortality (compared to grade 0: grade $1, \mathrm{HR} 1.93,95 \% \mathrm{CI}$ 1.37-2.73, grade 2, HR 2.19, 95\%CI 1.50-3.18, grade 3, HR 5.59, 95\%CI 3.34-9.39, $\mathrm{P}<0.0001)$. Similarly, anemia adjusted for the amount of transfused units of RBCs was not associated with poorer survival (HR 1.16, 95\%CI 0.91-1.47), whereas the number of transfused RBCs was associated with increased risk of late death (per RBC unit: RR 1.06, 95\%CI 1.04-1.08).

\section{Discussion}

The main finding of this study is that preoperative anemia is not associated with poorer survival when adjusted for baseline covariates and severity of perioperative bleeding.

Several studies showed that RBC transfusion is associated with increased mortality and morbidity after cardiac surgery $[8,21,22]$. In turn, anemic patients are more likely to receive transfusions $[7,10,11,13-15]$ and preoperative anemia itself has been shown to be a risk factor for adverse events [4,23-25]. However, the interaction between the anemia status and the increased need of transfusion makes difficult to disentangle the individual prognostic impact 
of these two factors. In their seminal contribution, Loor and colleagues [1] demonstrated the independent role of anemia and transfusion on the outcomes after cardiac surgery and concluded that both may have a significant and independent impact on adverse events. However, anemia and transfusion were assessed only intraoperatively and this prevented conclusive results on this issue. Indeed, using a different methodology and evaluating anemia, blood loss and transfusion during the entire postoperative period, preoperative anemia was not a risk factor for late mortality in propensity score matched pairs adjusted for exposure to blood products. The only adverse event associated with preoperative anemia was an increased risk of acute kidney injury. These findings were observed despite preoperative anemia was associated with significantly lower nadir haemoglobin levels without a difference in the amount of postoperative blood loss. However, some investigators consider anemia as a risk factor for increased bleeding because of its possible associated coagulopathy [26,27].

Since preoperative anemia is a modifiable condition, the hypothetical possibility to reverse its related risk of adverse events is intriguing. Evidence from previous studies suggests that the prevalence of preoperative anemia might be higher in cardiac surgery $[4,5,10,23]$, than in the general population of similar age, from developed countries [28-30]. Increased comorbidities among patients requiring revascularization might explain the difference. Older age [23], lower baseline eGFR [20] and poor left ventricular ejection fraction [31] are associated with higher incidence of anemia. In addition to these factors, the present study identified recent myocardial infarction and critical preoperative status as significantly associated with preoperative anemia. We speculate that lower hemoglobin values observed in these two patient groups might be due, in some patients with critical conditions, to hemodilutional anemia secondary to substantial preoperative infusion of fluids. 
However, the potential benefits of preoperative hemoglobin optimization are still unclear. Recent studies on the issue reported promising results. Preoperative treatment with EPO and/or intravenous iron is considered reasonable [32,33] and shown to reduce the need for RBC transfusion [34-36]. Hemoglobin optimization $>12 \mathrm{~g} / \mathrm{dL}$ was observed to improve the outcomes of Jehovah's witnesses undergoing cardiac surgery [37].

Our study has some limitations which should to be acknowledged. First, data collection was performed retrospectively. However, data on the amount of blood loss and use of blood products were recorded prospectively. This makes the estimation of perioperative bleeding and exposure to blood products rather reliable. Second, analysis limited to patients undergoing elective $\mathrm{CABG}$ would have enabled the exclusion of the impact of potential preoperative hemodilutional anemia, but it would have reduced the statistical power of this analysis. Importantly, propensity score matching provided pairs with similar prevalence of risk factors of critical prognostic importance. Third, this study does not address the possible multiple causes underlying preoperative anemia and some of them might have a prognostic impact which is left unrecognized. The strengths of the study are a relatively large database and a long follow-up with complete survival data.

\section{Conclusions}

In this study, preoperative anemia in patients undergoing CABG was associated with significant baseline comorbidities. When adjusted for important baseline characteristics and operative factors as well as for the severity of perioperative bleeding and the amount of transfused blood products, anemia was not associated with increased risk of adverse events. Increased exposure to blood transfusion among anemic patients may be the determinant of their poorer late survival. 


\section{Declaration of conflict of interests}

None to declare.

\section{Ethical approval details}

This study was approved by the Institutional Review Board of the Oulu University Hospital.

\section{Funding}

This study was not financially supported. 


\section{References}

1. Loor G, Rajeswaran J, Li L, et al (2013) The least of 3 evils: Exposure to red blood cell transfusion, anemia, or both? J Thorac Cardiovasc Surg 146:1480-1487

2. Ranucci M, Baryshnikova E, Castelvecchio S, et al (2013) Surgical and Clinical Outcome Research (SCORE) Group. Major bleeding, transfusions, and anemia: The deadly triad of cardiac surgery. Ann Thorac Surg 96:478-85

3. von Heymann C, Kaufner L, Sander M, et al (2016) Does the severity of preoperative anemia or blood transfusion have a stronger impact on long-term survival after cardiac surgery? J Thorac Cardiovasc Surg (Epub ahead of print)

4. Karkouti K, Wijeysundera DN, Beattie WS, (2008) Reducing Bleeding in Cardiac Surgery (RBC) Investigators. Risk associated with preoperative anemia in cardiac surgery: A multicenter cohort study. Circulation 117:478-84

5. Kulier A, Levin J, Moser R, et al (2007) Investigators of the Multicenter Study of Perioperative Ischemia Research Group, Ischemia Research and Education Foundation. Impact of preoperative anemia on outcome in patients undergoing coronary artery bypass graft surgery. Circulation 116:471-9

6. Spiegelstein D, Holmes SD, Pritchard G, et al (2015) Preoperative hematocrit as a predictor of perioperative morbidities following nonemergent coronary artery bypass surgery. J Card Surg 30:20-6

7. Musallam KM, Tamim HM, Richards T, et al (2011) Preoperative anaemia and postoperative outcomes in non-cardiac surgery: A retrospective cohort study. Lancet $378: 1396-407$ 
8. Oliver E, Carrio ML, Rodriguez-Castro D, et al (2009) Relationships among haemoglobin level, packed red cell transfusion and clinical outcomes in patients after cardiac surgery. Intensive Care Med 35:1548-55

9. Richards T, Musallam KM, Nassif J, et al (2015) Impact of preoperative anaemia and blood transfusion on postoperative outcomes in gynaecological surgery. PLoS One 10:e0130861

10. Hung M, Besser M, Sharples LD, et al (2011) The prevalence and association with transfusion, intensive care unit stay and mortality of pre-operative anaemia in a cohort of cardiac surgery patients. Anaesthesia $66: 812-8$

11. Society of Thoracic Surgeons Blood Conservation Guideline Task Force, Ferraris VA, Ferraris SP, Saha SP, et al (2007) Perioperative blood transfusion and blood conservation in cardiac surgery: The Society of Thoracic Surgeons and the Society of Cardiovascular Anesthesiologists clinical practice guideline. Ann Thorac Surg 83:S2786

12. Engoren MC, Habib RH, Zacharias A, et al (2002) Effect of blood transfusion on longterm survival after cardiac operation. Ann Thorac Surg 74:1180-6

13. Ranucci M, Di Dedda U, Castelvecchio S, et al (2012) Surgical and Clinical Outcome Research (SCORE) Group. Impact of preoperative anemia on outcome in adult cardiac surgery: A propensity-matched analysis. Ann Thorac Surg 94:1134-41

14. Matsuda S, Fukui T, Shimizu J, et al (2013) Associations between preoperative anemia and outcomes after off-pump coronary artery bypass grafting. Ann Thorac Surg 95:854-60

15. Kim CJ, Connell H, McGeorge AD, et al (2015) Prevalence of preoperative anaemia in patients having first-time cardiac surgery and its impact on clinical outcome. A 
retrospective observational study. Perfusion 30:277-83

16. Patel KV (2008) Epidemiology of anemia in older adults. Semin Hematol 45:210-7.

17. World Health Organization, Haemoglobin concentrations for the diagnosis of anaemia and assessment of severity. In: World Health Organization. Vitamin and Mineral Nutrition Information System (VMNIS). 2011, WHO/NMH/NHD/MNM/11.1 (http://www.who.int/vmnis/indicators/haemoglobin.pdf, accessed on July 21, 2016).

18. Nashef SA, Roques F, Sharples LD, et al (2012) EuroSCORE II. Eur J Cardiothorac Surg 41:734-44

19. Biancari F, Ruggieri VG, Perrotti A, et al (2015) European multicenter study on coronary artery bypass grafting (E-CABG registry): study protocol for a prospective clinical registry and proposal of classification of postoperative complications. J Cardiothorac Surg 10:90

20. Kidney Disease: Improving Global Outcomes (KDIGO) CKD Work Group, (2013) KDIGO 2012 Clinical practice guideline for the evaluation and management of chronic kidney disease. Kidney Inter Suppl 3:1-150

21. Shaw RE, Johnson CK, Ferrari G, et al (2013) Balancing the benefits and risks of blood transfusions in patients undergoing cardiac surgery: A propensity-matched analysis. Interact Cardiovasc Thorac Surg 17:96-102

22. Scott BH, Seifert FC, Grimson R, (2008) Blood transfusion is associated with increased resource utilisation, morbidity and mortality in cardiac surgery. Ann Card Anaesth $11: 15-9$

23. Miceli A, Romeo F, Glauber M, et al (2014) Preoperative anemia increases mortality and postoperative morbidity after cardiac surgery. J Cardiothorac Surg 9:137

24. Klein AA, Collier TJ, Brar MS, et al (2016) Association of Cardiothoracic 
Anaesthetists (ACTA). The incidence and importance of anaemia in patients undergoing cardiac surgery in the UK - the first association of cardiothoracic anaesthetists national audit. Anaesthesia 71:627-35

25. Fowler AJ, Ahmad T, Phull MK, et al (2015) Meta-analysis of the association between preoperative anaemia and mortality after surgery. Br J Surg 102:1314-24

26. Valeri CR, Cassidy G, Pivacek LE, et al (2001) Anemia-induced increase in the bleeding time: implications for treatment of nonsurgical blood loss. Transfusion 41:977-83

27. Ho CH, (1998) The hemostatic effect of packed red cell transfusion in patients with anemia. Transfusion 38:1011-4

28. Tettamanti M, Lucca U, Gandini F, et al (2010) Prevalence, incidence and types of mild anemia in the elderly: the "Health and Anemia" population-based study. Haematologica 95:1849-56

29. Martinsson A, Andersson C, Andell, P, et al (2014) Anemia in the general population: prevalence, clinical correlates and prognostic impact. Eur J Epidemiol 29:489-98

30. World Health Organization, (2008) World wide prevalence of anaemia 1993-2005, WHO global database on anaemia. (http://whqlibdoc.who.int/publications/2008/9789241596657_eng.pdf?ua=1, accessed on September 12, 2016)

31. Nijst P, Verbrugge FH, Bertrand PB, et al (2016) Plasma volume is normal but heterogeneously distributed and true anemia is highly prevalent in patients with stable heart failure. J Card Fail Epub ahead of print

32. American society of anesthesiologists task force on perioperative blood management, (2015) Practice guidelines for perioperative blood management: an updated report by 
the American Society of Anesthesiologists Task Force on Perioperative Blood Management. Anesthesiology 122:241-75

33. Society of thoracic surgeons blood conservation guideline task force, Ferraris VA, Brown JR, et al (2011) 2011 Update to The Society of Thoracic Surgeons and the Society of Cardiovascular Anesthesiologists Blood Conservation Clinical Practice Guidelines. Ann Thorac Surg 91:944-8.

34. Cladellas M, Farre N, Comin-Colet J, et al (2012) Effects of preoperative intravenous erythropoietin plus iron on outcome in anemic patients after cardiac valve replacement. Am J Cardiol 110:1021-1026

35. Sowade O, Warnke H, Scigalla P, et al (1997) Avoidance of Allogeneic Blood Transfusions by Treatment With Epoetin Beta (Recombinant Human Erythropoietin) in Patients Undergoing Open-Heart Surgery. Blood 89:411-8

36. Litton E, Xiao J, Ho KM, (2013) Safety and efficacy of intravenous iron therapy in reducing requirement for allogeneic blood transfusion: systematic review and metaanalysis of randomized clinical trials. BMJ 347:f4822

37. Tanaka A, Ota T, Uriel N, et al (2015) Cardiovascular surgery in Jehovah's witness patients: The role of preoperative optimization. J Thorac Cardiovasc Surg 150:976-83 


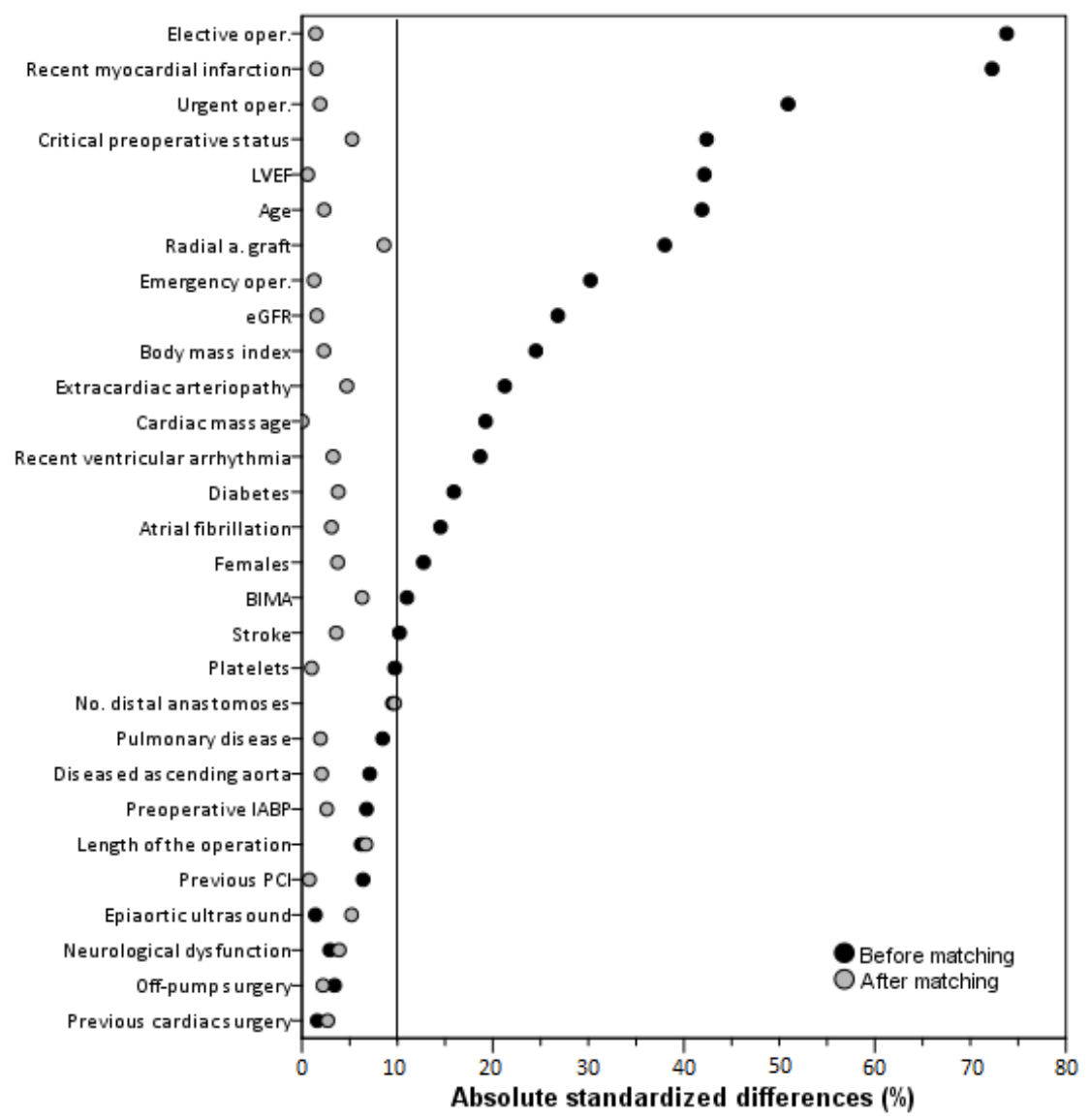

Figure 1. Absolute standardized difference before and after propensity score matching in the cohorts of patients with and without anemia. 


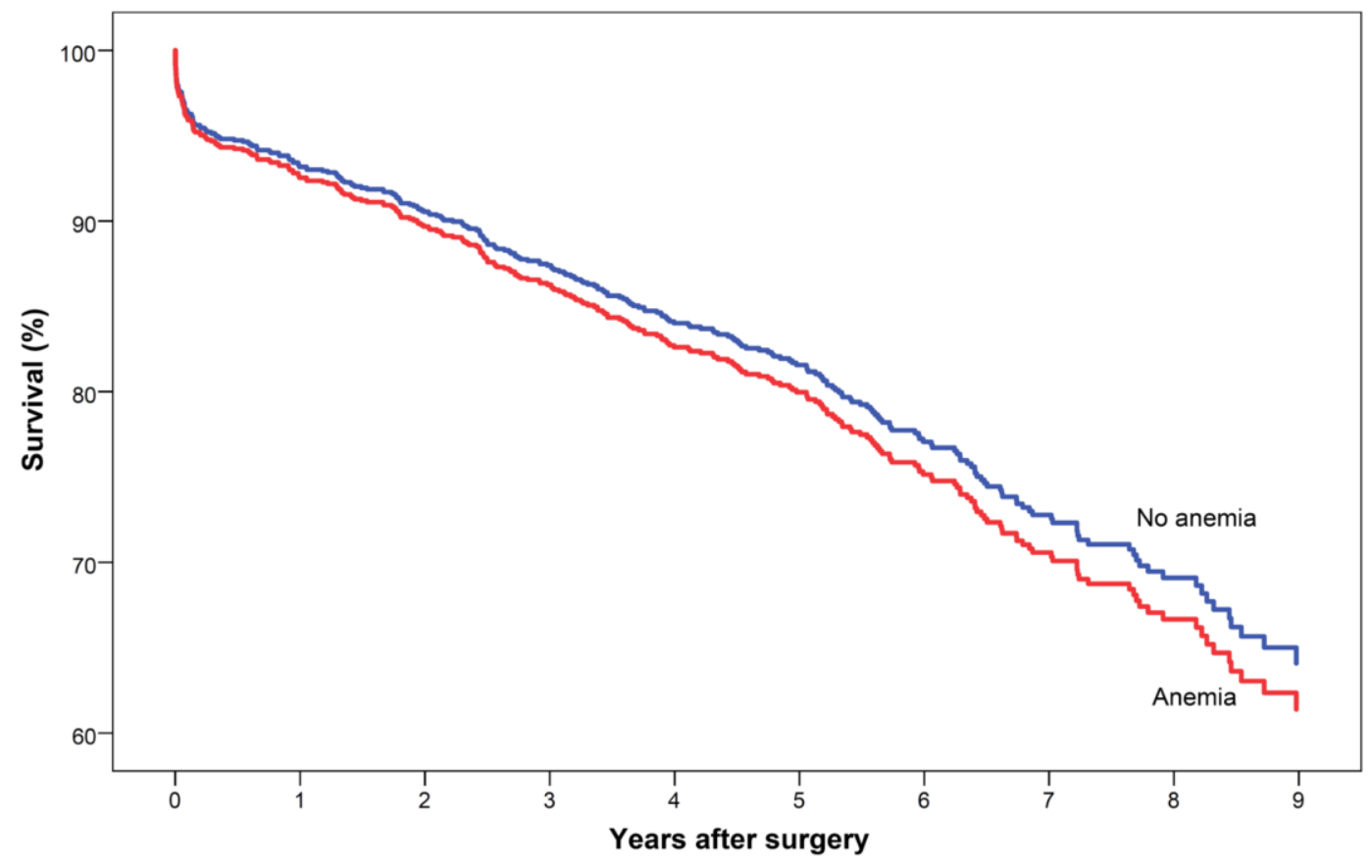

Figure 2. Cox proportional hazards estimate of survival in patients with and without anemia as adjusted by the E-CABG bleeding severity classification (HR, 1.10, 95\% CI 0.86-1.39). 
Table 1. Baseline characteristics.

\begin{tabular}{|c|c|c|c|c|c|c|c|}
\hline \multirow[b]{2}{*}{ Baseline variables } & \multirow[b]{2}{*}{$\begin{array}{c}\text { Overall } \\
\text { population } \\
\text { No. } 2761\end{array}$} & \multicolumn{2}{|c|}{ Overall series } & \multicolumn{4}{|c|}{ Propensity score matched pairs } \\
\hline & & $\begin{array}{c}\text { No preop. } \\
\text { anemia } \\
\text { No. } 2099\end{array}$ & $\begin{array}{l}\text { Preop. } \\
\text { anemia } \\
\text { No. } 662\end{array}$ & $P$-value & $\begin{array}{c}\text { No preop. } \\
\text { anemia } \\
\text { No. } 560\end{array}$ & $\begin{array}{c}\text { Preop. } \\
\text { anemia } \\
\text { No. } 560\end{array}$ & P-value \\
\hline Age (years) & $66.6 \pm 9.1$ & $66.2 \pm 9.1$ & $69.9 \pm 8.6$ & $<0.0001$ & $69.5 \pm 8.7$ & $69.7 \pm 8.5$ & 0.566 \\
\hline Females & $581(21.0)$ & $415(19.8)$ & $166(25.1)$ & 0.004 & $130(23.2)$ & $139(24.8)$ & 0.529 \\
\hline Body mass index & $28.1 \pm 4.5$ & $28.3 \pm 4.4$ & $27.2 \pm 4.6$ & $<0.0001$ & $27.5 \pm 4.2$ & $27.4 \pm 4.6$ & 0.664 \\
\hline Hemoglobin $(\mathrm{g} / \mathrm{dL})$ & $13.7 \pm 1.6$ & $14.4 \pm 1.1$ & $11.5 \pm 1.0$ & $<0.0001$ & $14.0 \pm 0.9$ & $11.6 \pm 1.0$ & $<0.0001$ \\
\hline Platelets $\left(10^{9} / \mathrm{L}\right)$ & $242 \pm 76$ & $240 \pm 69$ & $248 \pm 94$ & 0.600 & $247 \pm 84.8$ & $248 \pm 91$ & 0.983 \\
\hline eGFR $\left(\mathrm{mL} / \mathrm{min} / 1.73 \mathrm{~m}^{2}\right)$ & $86.1 \pm 25.2$ & $87.8 \pm 22.9$ & $80.5 \pm 31.0$ & $<0.0001$ & $82.8 \pm 23.9$ & $83.2 \pm 27.4$ & 0.359 \\
\hline Pulmonary disease & $274(9.9)$ & $195(9.3)$ & $79(11.9)$ & 0.047 & $59(10.5)$ & $62(11.1)$ & 0.773 \\
\hline Diabetes & $788(28.5)$ & $562(26.8)$ & $226(34.1)$ & $<0.0001$ & $187(33.4)$ & $177(31.6)$ & 0.523 \\
\hline Stroke & $95(3.4)$ & $62(3.0)$ & $33(5.0)$ & 0.012 & $20(3.6)$ & $24(4.3)$ & 0.538 \\
\hline Extracardiac arteriopathy & $265(9.6)$ & $168(8.0)$ & $97(14.7)$ & $<0.0001$ & $78(13.9)$ & $69(12.3)$ & 0.426 \\
\hline Neurological dysfunction & $50(1.8)$ & $36(1.7)$ & $14(2.1)$ & 0.501 & $15(2.7)$ & $12(2.1)$ & 0.559 \\
\hline Atrial fibrillation & $282(10.2)$ & $191(9.1)$ & $91(13.7)$ & 0.001 & $63(11.3)$ & $69(12.3)$ & 0.578 \\
\hline Previous PCI & $199(7.2)$ & $143(6.8)$ & $56(8.5)$ & 0.153 & $40(7.1)$ & $41(7.3)$ & 0.908 \\
\hline Previous cardiac surgery & $46(1.7)$ & $36(1.7)$ & $10(1.5)$ & 0.72 & $6(1.1)$ & $8(1.4)$ & 0.591 \\
\hline $\begin{array}{l}\text { Left ventricular ejection fraction } \\
\leq 50 \%\end{array}$ & $697(26.2)$ & 435 (21.6) & $262(40.7)$ & $<0.0001$ & $213(38.0)$ & $211(37.7)$ & 0.902 \\
\hline Recent myocardial infarction & 1317 (47.7) & $832(39.6)$ & $485(73.3)$ & $<0.0001$ & $400(71.4)$ & $396(70.7)$ & 0.792 \\
\hline Critical preoperative status & $217(7.9)$ & $99(4.7)$ & $118(17.8)$ & $<0.0001$ & $71(12.7)$ & $81(14.5)$ & 0.383 \\
\hline Preoperative IABP & $11(0.4)$ & $6(0.3)$ & $5(0.8)$ & 0.147 & $4(0.7)$ & $3(0.5)$ & 1.000 \\
\hline Inotropic support & $67(2.4)$ & $25(1.2)$ & $42(6.3)$ & $<0.0001$ & $17(3.0)$ & $22(3.9)$ & 0.415 \\
\hline Recent ventricular arrhythmia & $83(3.0)$ & $45(2.1)$ & $38(5.7)$ & $<0.0001$ & $25(4.5)$ & $29(5.2)$ & 0.577 \\
\hline Cardiac massage & $43(1.6)$ & $18(0.9)$ & $25(3.8)$ & $<0.0001$ & $14(2.5)$ & $14(2.5)$ & 1.000 \\
\hline
\end{tabular}

Continuous variables are reported as mean and standard deviation. Categorical variables are reported as counts

and percentages. PCI: percutaneous coronary intervention. IABP: intra-aortic balloon pump. eGFR: estimated glomerular filtration rate. 
Table 2. Operative data.

\begin{tabular}{|c|c|c|c|c|c|c|c|}
\hline \multirow[b]{2}{*}{ Operative variables } & \multirow[b]{2}{*}{$\begin{array}{c}\text { Overall } \\
\text { population } \\
\text { No. } 2761\end{array}$} & \multicolumn{2}{|c|}{ Overall series } & \multicolumn{4}{|c|}{ Propensity score matched pairs } \\
\hline & & $\begin{array}{c}\text { No preop. } \\
\text { anemia } \\
\text { No. } 2099\end{array}$ & $\begin{array}{c}\text { Preop. } \\
\text { anemia } \\
\text { No. } 662\end{array}$ & $P$-value & $\begin{array}{c}\text { No preop. } \\
\text { anemia } \\
\text { No. } 560\end{array}$ & $\begin{array}{c}\text { Preop. } \\
\text { anemia } \\
\text { No. } 560\end{array}$ & $\begin{array}{c}P- \\
\text { value }\end{array}$ \\
\hline Urgency status & & & & $<0.0001$ & & & 0.950 \\
\hline Elective & 1259 (45.6) & $1125(53.6)$ & $134(20.2)$ & & $124(22.1)$ & $127(22.7)$ & \\
\hline Urgent & $1306(47.3)$ & $869(41.4)$ & $437(66.0)$ & & $375(67.0)$ & $370(66.1)$ & \\
\hline Emergency & $196(7.1)$ & $105(5.0)$ & $91(13.7)$ & & $61(10.9)$ & $63(11.3)$ & \\
\hline Off-pump surgery & $1507(54.6)$ & $1137(54.2)$ & $370(55.9)$ & 0.438 & $315(56.3)$ & $309(55.2)$ & 0.718 \\
\hline Epiaortic ultrasound & $1448(52.4)$ & $1097(52.3)$ & $351(53.0)$ & 0.733 & $311(55.5)$ & $296(52.9)$ & 0.368 \\
\hline Diseased ascending aorta & $225(8.1)$ & $161(7.7)$ & $64(9.7)$ & 0.101 & $50(8.9)$ & $53(9.5)$ & 0.756 \\
\hline Number of distal anastomoses & $4.0 \pm 1.1$ & $4.0 \pm 1.1$ & $3.9 \pm 1.1$ & 0.510 & $4.0 \pm 1.0$ & $3.9 \pm 1.0$ & 0.977 \\
\hline Length of the operation (min) & $249 \pm 69$ & $249 \pm 71$ & $246 \pm 62$ & 0.324 & $248 \pm 54$ & $244 \pm 56$ & 0.569 \\
\hline
\end{tabular}

Continuous variables are reported as mean and standard deviation. Categorical variables are reported as counts

and percentages. CPB: cardiopulmonary bypass. 
Table 3. Bleeding-related outcomes.

\begin{tabular}{|c|c|c|c|c|c|c|c|}
\hline & \multirow[b]{2}{*}{$\begin{array}{c}\text { Overall } \\
\text { population } \\
\text { No. } 2761\end{array}$} & \multicolumn{2}{|c|}{ Overall series } & \multicolumn{4}{|c|}{ Propensity score matched pairs } \\
\hline & & $\begin{array}{c}\text { No preop. anemia } \\
\text { No. } 2099\end{array}$ & $\begin{array}{l}\text { Preop. anemia } \\
\quad \text { No. } 662\end{array}$ & $P$-value & $\begin{array}{c}\text { No preop. anemia } \\
\text { No. } 560\end{array}$ & $\begin{array}{l}\text { Preop. anemia } \\
\quad \text { No. } 560\end{array}$ & $P$-value \\
\hline Nadir hemoglobin $(\mathrm{g} / \mathrm{dL})$ & $8.3 \pm 1.2$ & $8.5 \pm 1.2$ & $7.6 \pm 0.9$ & $<0.0001$ & $8.3 \pm 1.1$ & $7.6 \pm 0.9$ & $<0.0001$ \\
\hline Blood loss at 12 hours (mL) & $504 \pm 394$ & $509 \pm 388$ & $484 \pm 416$ & 0.029 & $494 \pm 376$ & $477 \pm 414$ & 0.408 \\
\hline $\mathrm{RBC}$ transfusion & $1753(63.5)$ & $1160(55.3)$ & $593(89.6)$ & $<0.0001$ & $393(70.2)$ & $497(88.8)$ & $<0.0001$ \\
\hline RBC units transfused & $2.5 \pm 3.4$ & $1.9 \pm 2.8$ & $4.5 \pm 4.2$ & $<0.0001$ & $2.7 \pm 3.7$ & $3.9 \pm 3.5$ & $<0.0001$ \\
\hline Octaplas transfusion & $737(26.7)$ & $514(24.5)$ & $223(33.7)$ & $<0.0001$ & $174(31.1)$ & $175(31.3)$ & 1.000 \\
\hline Octaplas units transfused & $1.2 \pm 2.4$ & $1.0 \pm 2.1$ & $1.7 \pm 3.3$ & $<0.0001$ & $1.3 \pm 2.4$ & $1.3 \pm 2.6$ & 0.546 \\
\hline Platelet transfusion & $824(29.8)$ & $562(26.8)$ & $262(39.6)$ & $<0.0001$ & $192(34.3)$ & $202(36.1)$ & 0.568 \\
\hline Platelet units transfused & $3.0 \pm 6.1$ & $2.5 \pm 5.0$ & $4.5 \pm 8.6$ & $<0.0001$ & $3.4 \pm 6.1$ & $3.4 \pm 6.1$ & 0.178 \\
\hline Resternotomy for bleeding & $180(6.5)$ & $139(6.6)$ & $41(6.2)$ & 0.697 & $40(7.1)$ & $29(5.2)$ & 0.222 \\
\hline $\begin{array}{l}\text { Procedure of retained blood } \\
\text { within } 30 \text { days }\end{array}$ & $253(9.2)$ & $191(9.1)$ & $62(9.4)$ & 0.836 & $58(10.4)$ & $45(8.0)$ & 0.198 \\
\hline E-CABG bleeding grades & & & & 0.001 & & & $<0.0001$ \\
\hline Grade 1 & $1116(40.4)$ & $819(39.0)$ & $297(44.9)$ & & $257(45.9)$ & $259(46.3)$ & \\
\hline Grade 2 & $504(18.3)$ & $283(13.5)$ & $221(33.4)$ & & $101(18.0)$ & $183(32.7)$ & \\
\hline Grade 3 & $68(2.5)$ & $27(1.3)$ & $41(6.2)$ & & $15(2.7)$ & $25(4.5)$ & \\
\hline
\end{tabular}

Continuous variables are reported as mean and standard deviation. Categorical variables are reported as counts and percentages. RBC:

red blood cell. 
Table 4. Outcomes in the overall series and in propensity score matched cohorts.

\begin{tabular}{|c|c|c|c|c|c|c|c|c|}
\hline & \multicolumn{4}{|c|}{ Overall series } & \multicolumn{2}{|c|}{ Propensity score matched pairs } & \multirow[b]{2}{*}{$\begin{array}{l}\text { Univariate } \\
\text { analysis } \\
P \text {-value }\end{array}$} & \multirow[b]{2}{*}{$\begin{array}{c}\text { Adjusted analysis } \\
\text { Risk estimate } \\
(95 \% \text { CI })\end{array}$} \\
\hline & $\begin{array}{c}\text { Overall } \\
\text { population } \\
\text { No. } 2761\end{array}$ & $\begin{array}{c}\text { No preop. anemia } \\
\text { No. } 2099\end{array}$ & $\begin{array}{c}\text { Preop. anemia } \\
\text { No. } 662\end{array}$ & $\begin{array}{c}\text { Univariate } \\
\text { analysis } \\
P \text {-value }\end{array}$ & $\begin{array}{c}\text { No preop. anemia } \\
\text { No. } 560\end{array}$ & $\begin{array}{l}\text { Preop. anemia } \\
\text { No. } 560\end{array}$ & & \\
\hline In-hospital death & $66(2.4)$ & $38(1.8)$ & $28(4.2)$ & $<0.0001$ & $18(3.2)$ & $17(3.0)$ & 1.000 & $0.61,0.31-1.23$ \\
\hline 30-day mortality & $89(3.2)$ & $48(2.3)$ & $41(6.2)$ & $<0.0001$ & $22(3.9)$ & $22(3.9)$ & 1.000 & $0.67,0.36-1.26$ \\
\hline ICU stay (days) & $2.2 \pm 2.5$ & $1.9 \pm 2.0$ & $2.9 \pm 3.5$ & $<0.0001$ & $2.4 \pm 2.6$ & $2.6 \pm 3.1$ & 0.155 & $-0.29,-0.62-0.04$ \\
\hline Stroke & $58(2.1)$ & $33(1.6)$ & $25(3.8)$ & 0.001 & $14(2.5)$ & $17(3.0)$ & 0.719 & $0.93,0.45-1.93$ \\
\hline Atrial fibrillation & $1185(42.9)$ & $848(40.4)$ & $337(50.9)$ & $<0.0001$ & $276(49.3)$ & 278 (49.6) & 0.951 & $0.95,0.74-1.20$ \\
\hline Ventricular fibrillation/asystole & $48(1.7)$ & $24(1.1)$ & $24(3.6)$ & $<0.0001$ & $11(2.0)$ & $18(3.2)$ & 0.265 & $1.13,0.52-2.47$ \\
\hline Permanent pace-maker implantation & $18(0.7)$ & $11(0.5)$ & $7(1.1)$ & 0.163 & $4(0.7)$ & $6(1.1)$ & 0.754 & $1.39,0.38-5.12$ \\
\hline Low cardiac output syndrome & $382(13.8)$ & $267(12.7)$ & $115(17.4)$ & 0.003 & $95(17.0)$ & $92(16.4)$ & 0.870 & $0.78,0.54-1.05$ \\
\hline Postop. intra-aortic balloon pump & $16(0.6)$ & $11(0.5)$ & $5(0.8)$ & 0.556 & $6(1.1)$ & $4(0.7)$ & 0.754 & $0.46,0.13-1.68$ \\
\hline Repeat CABG or PCI & $14(0.5)$ & $10(0.5)$ & $4(0.6)$ & 0.753 & $1(0.2)$ & $3(0.5)$ & 0.625 & $1.67,0.17-16.24$ \\
\hline Post-operative use of antibiotics & $935(33.9)$ & $613(29.2)$ & $322(48.6)$ & $<0.0001$ & $211(37.7)$ & $258(46.1)$ & 0.004 & $1.17,0.91-1.50$ \\
\hline Deep sternal wound infection & $40(1.4)$ & $26(1.2)$ & $14(2.1)$ & 0.1 & $7(1.3)$ & $10(1.8)$ & 0.629 & $1.24,0.46-3.35$ \\
\hline Mediastinitis & $43(1.6)$ & $29(1.4)$ & $14(2.1)$ & 0.184 & $10(1.8)$ & $10(1.8)$ & 0.181 & $0.88,0.35-2.18$ \\
\hline Surgery for gastrointest. compl. & $32(1.2)$ & $16(0.8)$ & $16(2.4)$ & 0.001 & $6(1.1)$ & $10(1.8)$ & 0.454 & $1.03,0.36-2.95$ \\
\hline Acute kidney injury & & & & $<0.0001$ & & & $<0.0001$ & $-0.31,-0.60--0.01$ \\
\hline Grade 1 & $325(12.0)$ & $181(8.7)$ & $144(23.0)$ & & $71(12.9)$ & $124(22.4)$ & & \\
\hline Grade 2 & $71(2.6)$ & $40(1.9)$ & $31(4.9)$ & & $17(3.1)$ & $25(4.5)$ & & \\
\hline Grade 3 & $61(2.3)$ & $33(1.6)$ & $28(4.5)$ & & $17(3.1)$ & $21(3.8)$ & & \\
\hline New renal replacement therapy & $51(1.9)$ & $28(1.3)$ & $23(3.6)$ & $<0.0001$ & $16(2.9)$ & $17(3.0)$ & 1.000 & $0.61,0.29-1.29$ \\
\hline Acute kidney injury without dialysis & $396(14.3)$ & $223(10.6)$ & $173(26.1)$ & $<0.0001$ & $89(15.9)$ & $147(26.3)$ & $<0.0001$ & $1.50,1.10-2.03$ \\
\hline Survival** & & & & $<0.0001$ & & & 0.047 & $1.10,0.86-1.39$ \\
\hline 1-year & & $96.0 \%$ (2015) & $88.7 \%(587)$ & & $92.9 \%(520)$ & $92.0 \%(515)$ & & \\
\hline 5 -year & & $88.4 \%(1287)$ & $72.7 \%(319)$ & & $82.9 \%(315)$ & $76.9 \%(280)$ & & \\
\hline 8 -year & & $80.2 \%(471)$ & $62.4 \%(82)$ & & $68.2 \%(104)$ & $66.3 \%(72)$ & & \\
\hline
\end{tabular}

significance in multivariate analysis; ICU: intensive care unit; CABG: coronary artery bypass grafting; PCI: percutaneous coronary intervention; Risk estimates are odds ratio or beta coefficient; $95 \% \mathrm{CI}$ : $95 \%$ confidence interval; *: excluding bleeding-related outcomes; $* *$ : in parentheses are patients at risk. 